\title{
Devletin menşeini içtimaî mukaveleye istinat ettiren nazariyeler
}

\author{
Doçent Dr. Muvaffak AKBAY
}

lçtimaî mukavele nazariyesi, devletin menşeini insanın akıl ve iradesine istinat ettiren nazariyenin tekâmül etmiş şeklidir. [1] Gerek çok eski devirlerdenberi mevcut olması ve ön planda gelen birçok müellifler tarafından ileri sürülmüş bulunması, gerekse, muasır devlet teorisi üzerindeki derin tesirleri bakımından, hususî bir önemi haizdir.

İçtimaî mukavele nazariyesinin tarihçesini yapmadan ve bir müelliften diğerine arzettił̆i hususiyetleri belirtmeden önce, nazariyenin, bütün müelliflere müşterek olan ana hatlarını tebarüz ettirmek dogru olur.

Nazariyenin esas prensibi, devletin menşeinin bir mukaveleye istinat ettiği ve bu mukaveleden önce, insanların hayatında, müşterek bir otoriteye tâbi olmadıklanı teşkilâtsız bir devrenin mevcut bulunduğu fikridir. Bu, hukuk dişı (extralégal) veyahut hukuktan önce (prélégal) mevcudiyeti kabul edilen devreye, müellifler tabiat hali (status naturae) adını vermektedirler.

Tabiat halinde, bir kısım müelliflere göre, insanlar, sulh ve sükûn içinde mes'ut yaşamaktadırlar. Diğer bir kısım müellifler ise, bilâkis, insanların tabiat halinde, son derece bedbaht oldukların, zira birçok tehlikelere maruz bulunduklarını iddia etmektedírler. Bunlara göre, tabiat halinde, hodbinlik ve kuvvetlilerin zayıflara tahakkümü hiçbir sınır tanımamakta idi.

Tabiat halini gerek iyi gerekse kötü olarak kabul eden içtimaî mukavele nazariyesi taraftarlarının hepsinin birleştikleri cihet, günün birinde, insanlarn şu veya bu sebebin tesiriyle bu hali birakarak, toplu bir şekilde yaşamăga karar vermiş bulunmalarıdır.

[1] Okandan, Devletin menşei, l̇stanbul 1945, S. 64. 
Bu kararn neticesindedir $\mathrm{ki}$, insanlar, tabiat halinden (status naturae) cemiyet haline (status societatis) geçmiş oldular.

Cemiyet haline geçiş, insanların, aralarında, karşlıklık olarak, birbirlerinin haklarına riayet edeceklerine ve bir arada sulh içinde yaşayacaklarına dair bir mukavele akdetmeleri sayesinde vukua geldi (pactum unionis). Işte cemiyete, devlete vücut veren bu anlaşmanın adına içtimât mukavele denilmektedir.

Gerek bu mukaveleye ilâveten, gerekse, içtimaî mukaveleden sonra yapllan diğer bir anlaşma ile de, egemenliğe sahip olduğu farzedilen halk, bu egemenligi, veya sadece onun istimalini, bir şahsa, bir meclise veya doğrudan doğruya topluluğa devretti. Başka bir söyleyiş şekliyle, bu ikinci mukavele ile insanlar, kendilerini idare edecek olanı veya olanları seçtiler ve bu kimseye veya kimselere tâbi bulunmağı taahhüt ettiler. Siyasî teşkilâtı vücude getiren bu anlaşmanın adına da siyasî̀ mukavele denilmektedir. [2]

Görülüyor ki, içtimaî mukavele nazariyesinin ortaya koyduğu esas fikir, siyasî iktidarın halkten geldị̣̆i prensibidir.

Ancak, bu prensip üzerinde ittifak eden içtimâi mukavele taraftarları bundan birbirlerine taban tabana zıt neticeler çıarmaktadırlar. Filhakika, bunlardan bir kısmına göre, mademki egemenlik esas itibariyle halktadır, siyasî iktidar halktan gelmektedir, o halde, idare eden veya edenler, mukavele mucibince kendilerine düşen vazifeleri yapmadıkları taktirde, halk onlarm elinden iktidarı geri alabilir.

Buna mukabil, diğer bir kısım müellifler de, halkın mukavele ile egemenliği idare edene veya edenlere terketmiş olduğunu ve itibarla artık bu hakkından tamamen vazgeçmiş sayılacağını ve bir daha ona sahip olamıy acağını ileri sürmektedirler.

Bu suretle, içtimaî mukaveie nazariyesi, bir müeiliften diğer müellife, hem demokrasiye, hem de müstebit idare tarzına esas teşkil edecek şekilde tefsir ve izah olunmaktadır.

lçtimaî mukavele nazariyesinin köklerini çok eski devirlerde bulmann mümkün olduğunu kaydetmiştik. Gerçekten, Milattan önce beşinci yüz yılda yaşamış olan Sofist'lerde bu nazariyenin izlerine rastlanır. [3] Meselâ bunların en meşhurlarından biri olan

[Q] Rousseau : Contrat social, kitap I, Bölüm V.

[?] Jellinek, L'Etat moderne et son droit C. 1, S. $32 z$. 
Protagoras insanların, adaletsizlikten korunmak üzere iradî bir anlaşmaya vardıklarını iddia eder. Fakat, içtimaî mukavele nazariyesini, tam bir vuzuhla, ilk defa Epicure'de buluruz. Epicure (M. E. 342 - 271) insanın içtimaî bir mahlûk olduğunu inkâr etmektedir. Ona göre, başlangıçta insan hemcinsleri ile mütemadi bir mücadele halinde idi. Fakat bu mücadele, onun için bir iztirap kaynă̆ı teşkil ettił̆inden, günün birinde karşlıklı bir anlaşma ile devlet vücuda geldi. Binaenaleyh, Yunan filozofuna göre, hukuk ve devlet, kendisinden muayyen ve karşlıkh bir faide beklenen bir mukaveleye istinat eder. Bu itibarla, beklenilen bu faide temin edilmediğ́i gün mukavele de fesholunabilir. [4]

Orta çăgda, içtimaî mukavele nazariyesine fazla rał̧bet edilmiş değgildir. Bunun sebebini hrristiyanlı̆̆ın bütün bir çặ̛a hâkim olan felsefesinde, dünya devletinin ilk günah mahsulü olarak ielâkki edilmesinde bulmak mümkündür. [5] Bununla beraber, bu devrin en mühim iki müellifi olan Saint - Thomas (1227 - 1274) da ve bilhassa Marsile de Padoue $(1270-1342)$ da bu nazariyeye rastlanır. Ileri ve cesur fikirleriyle zamanının çok üstüne yükselmiş olan Marsile de Padoue'ya göre, tabiat halinde hür yaşayan insanlar, bu hürriyetlerini anarşi ve emniyetsizlikten kurtarmak, muhtaç oldukları şeyleri kolaylıkla tedarik edebilmek ve kendilerini tehdit eden tehlikeleri birlikte savuşturmak için siyasî toplulukları vücude getirmişlerdir. Binaenaleyh, herbirinin o topluluð̆un kaidelerinin kendileri için faideli olup olmadığını takdir etmeğe, yani başka bir söyleyişle, kanunlar yapilırken bu hususta rey sahibi bulunmağa hakkı vardır. Halk hükûmdara egemenliŏini dev. retmiş deł̆ildir. Hükûmdara ancak (siyasî mukavele) ile bunun istimalini bırakmıştır. Bu itibarla, prens, egemenliłgi gayesine uygun bir şekilde, yani halkın menfaatini gözeterek kullanmadığı taktirde mukavele münfesih olur. Prens bir vasttadan, bir âletten ibarettir. Iktidarını halktan alır ve onun tesbit ettiği hudutları aşamaz. [5]

Içtimaî mukavele nazariyesi, Renaissance ve Réforme hareketleriyle birlikte büyük bir revaca mazhar olmuştur. Ezcümle Suarez (1548-1617), R. Hooker $(1554-1600)$, Altusius $(1557-1638)$ gibi müelliflerde bu doktrine rastlartz. [6]

[4] Del Vechio, Leçons de philosophie du droit, Paris 1936, S. 39.

[5] Jeilinek, op. cit, C. J, S. 326

[5] Janet, Histojre de la seience politiqne dans ses rapports avec la morale e. 1 , s. 460 .

[6] Tafsilât için Bk. R. Okandan, op. cit., S. $73-79$. 
XVII nci ylln büyük müelliflerinin hemen hepsi içtimaî nazariyeyi benimsemişlerdir. Ezcümle Hobbes (1588-1679), Lucke (1632 - 1704), Grotius (1583 - 1645), Spinoza (1632-1677), Puffendorf $(1632-1694)$ Bos suet $(1627-1704)$ gibi filozoflar, eserlerinde devletin menşeini içtimaî mukaveleye istinat ettirmişlerdir.

A - Hobbes: Bir ingiliz filozofu olan Hobbes siyasì doktrinini (Insan tabiatı bakıminda - De la nature humaine), (Vatandaş hakkında - De Cive) ve (Ejderha - Leviathan) adiı meşhur üç eserinde izah eder.

Hobbes'a göre, insan, yalnız hisleriyle bilgi edinebilir. Harici âlemdeki hâdiseler, hislerimize "şekiller" ve «renklers halinde çarparlar. Bu temas neticesinde asabumiz harekete gelir. Bu hareket kalbe (uzviyet) intikal ettiği zaman "zevk" veya selem" şekline inkılâp eder. Bunun neticesinde, zevk veren hâdiselere karş̣ "sevgi", elem verenlere karşı da "nefret" duyarız. Insanlar tabiatları iktizası, zevk veren şeyleri arzu ederler iztirap verenlerden korkarlar ve kaçınırlar. Başka bir tâbir ile, insanlar tabiaten bencildirler. Yegâne düşünceleri, zatî iyiliklerini aranıaktır. Onlar için lezzet veren her șey «iyi elem veren her şey skötü: dür. En büyük jyilik "nefsin korunması en büyük fenalık ise sölüm? dür. Binaenaleyh, tabiî hukukun esas prensibi, insanın nefsini elinden geldiği kadar korumasıdır. Bu gaye uğruna, her vasıtaya müracaat, insanın tabiî hakkıdrr. Diğer taraftan, insan, nefsini korumak için başvuracağı vasıtaları seçmekte mutlak bir salâhiyete maliktir. Bunun neticesi olarak, kendisine bu hususta faideli olabilecek her şey üzerinde de tcbit bir hakkı vardır.

Hobbes, başlangıçta bir *tabiat hali» tasavvur etmektedir. Bu tabiat halinde, insanlar birbirine müsavidirler [7]. Çünkü birbirine ayn derecede fenalik yapabilirler. Yani, herkes herkesi öldürmek kudretine sahiptir. Vakı, kuvvet farkı bunlar arasında da mevcuttur. Ancak, bunun ehemmiyeti yoktur. Zira, en kuvvetli insan bile hile ile kolayca öldürülebilir. Demek oluyor ki, tabiat halinde, bütün insanların iktidarlan birbirlerine eştir. Bunun neticesi olarak herkes müsavidir ve her şey üzerinde ayn haklara sahiptir.

Bütün insanların, her şey üzerinde ayn hakka sahip oldukların ileri sürmek bunlarn, birbiriyle mütemadiyen harp halinde

[7] Hobbes. De Cive, La litrerté B. 1, Ill. 
bulundukların kabul etmek demektir. Gerçekten, Hobbes, tabiat halinde insanların birbirleriyle devamlı surette mücadele ettiklerini belirtmektedir, çünkü, bir şeyin mülkiyetini edinmek veya muhafaza etmek isteyen bir kimse, o sey üzerinde hak iddia eden diğer insanlarla savaşmak mecburiyetindedir. Aynı şey, aynı zamanda birçok kimseler tarafından arzu edildiği taktirde, hepsinin o şey üzerindeki hakları birbirine müsavi olduğuna göre, onu, ancak mücadele neticesinde galip gelen ele geçirebilecektir. Yalnız, bu sonuncu da, malını muhafaza edebilmek için mütemadiyen savaşmał̆ı göze almalıdır. Insanlar arasındaki bu mütemadi mücadelenin bir diğer sebebi de, herkesin kendi fikrinin doğruluğuna inanmış olmasıdır. Karşısındaki eğer kendisinden başka bir kanaatta ise, bunlar birbirine kin beslemege başlıyacaklar, ve nihayet bu hal, kavga ile neticelenecektir. Nitekim, hattâ medenî cemiyetlerde bile, bunun misalleri din muharebeleri veya politika mücadeleleri şeklinde görülmektedir. [8]

Iște bütün bu sebeplerden dolayı «tabiat hali» nde insanlar, birbiriyle mütemadi bir savaşa girişmișlerdir. Herkes, herkesin düşmanıdır, insan insanın kurdudur (Homo homini lupus). Hobbes, Aristo'nun "insanın içtimaî bir mahlūk " oldư̆u hakkındaki tikrini kabul etmemektedir. Ona göre bu söz, tamamen yanlıştır. [9] Hiç şüphesiz, insan için mütemadi bir yainızlı içinde bulunmak tahammülfersa bir şeydir. Cocukların yaşamak için, büyüklerin daha iyi yaşayabilmek için, diğer insanların yardım ve himayelerine ihtiyaçları vardır. Bu itibarla, tabiatın bizi hemcinslerimizle bir arada bulunmağa sevkettiği inkâr olunamaz. Ancak, bu beraberlik arzusu, insanların tabiaten içtimai bir mahlûk olmaları ve bu yüzden medeni cemiyetler tesis etmiş bulunmaları için kâfi bir sebep degyildir. Bu his, sadece, muvakkat birliklerin vücut bulmasına yarayabilir. Halbuki, medeni cemiyetier bir takım mukavelelere istinat ederler ve devamlıdırlar. Eğer mesele daha yakından incelenecek olursa, insanların tabiaten içtimaî olmadıkları, fakat, bazı menfaatlerini korumak için bir araya geldikleri anlaşılır. Hülâsa, insanlar, hemcinslerini sevdiklerinden değil, fakat menfaatları iktizası birleşirler. Esasen, cemiyet halindeki insanların müşahedesi, onlarm birbirlerine karşı muhabbet beslediklerini deg̛il, fakat, hepsinin birbirlerine tahakküm etmek istediklerini ve yalnız men-

[8] Hobbes, De Cive, La libertè B. i, V.

[9] Hobbes, De Cive, La liberté B. I, Il. 
faał kaygusu ile bir arada bulundukların isbata kâfidir. Çünkü, cemiyet halinde bile, insanlar arasindaki mücadele büsbütün bitmiş değildir. Kıskançlıkların, rekabetlerin, dedikoduların cemiyet hayatında dahi devam etmesi, insanların tabiaten birbiriyle mücadeleye meyyal olduklarımın en güzel delilidir. Demek oluyor ki, cemiyet, insanların içtimailik hislerine değil, bu şekilde yaşamanın menfaatlarina daha uygun olmasina istinat eder. Cemiyet hayatının insanlara temin ettiği en büyük menfaat, onların, tabiat halinde birbirlerine karşı duydukları korkuyu ortadan kaldırmasıdır.

Tabiat halinde, insanların birbiriyle mütemadi bir mücadele içinde buiunmalarının neticesi olarak, cemiyetten önce, ne adalet, ne hak, ne de mülkiyet mefhumları vardır. Çünkü, adalet ve hukuk, insanların insan almak haysiyetiyle değil fakat vatandaşlık sifatiyle beraber, yani, cemiyet hayatiyle birlikte edindikleri mefhumlardır. Beşeriyet için, ölüm, en büyük fenalık olduğuna ve tabiat halinde de, insanlar, daima ölüm korkusu ile yaşadıklarına göre, birlikte yaşamağa başiamadan önce, onların çok fena bir bir durumda olduklanı muhakkaktır. Çünkü, devamlı bir endişe içindedirler ve hiç kimse hayat ve selâmetinden emin değildir. Binaenaleyh, onlar için, bu kötü vaziyetten kurtulmak ve «sulhs e varmak lâzımdir. Insanların sulh ve sükûne kavuşnak istemeleri bir stabiat kanunu= dur. Hobbe'a göre, burada tabiał kantinu - akhn insanlara emrettiği şey demektir. Nasıl, nefsi korumak için, icap eden her şey üzerinde herkesin tabiî bir hakkı varsa, tabiat kanunu da gene nefsi korumak için, onları, kendilerine tehlikeli olabilecek hareketlerden meneden bir mantık kaidesidir. Bu suretie "tabiî hak"1 "tabiat kanunu* tahdit etmektedir. Yani, insanlar için gaye nefsin muhafazası olduğuna göre, bu uğurda herkes her vasitaya müracaat ve her şey üzerinde hak iddia etmeğe salâhiyettardur. Ancak, bu hal, onlar arasında mütemadi bir mücadele doğurmaktadır. Halbuki, mücadele, insanların selâmetine en büyük engeldir. Çünkü hiç kimsenin, kuvvetinden ve zekâsından her zaman emin olmasına imkân yoktur ve bu itibarla, mağlup olmak ihtimali daima mevcuttur. Isste, mantık, bu engeli ortadan kaldırmağı, başka bir tabirle «sulh , e vasıl olmağı emreder. Binaenaleyh, Hobbes'a göre "tabiat kanunu» nun ilk prensibi şudur: Insanlar «sulh» e kavuşmak çarelerini aramalıdırlar. Demek oluyor ki, tabiat, insanları, nefislerini korumak için, buna yarayacak her şeyi istemeğe sevkeyliyor. Fakat, diğer taraftan da 
yine tabiatm bir tecellisi olan akliselim, onlara, kendilerini tehlikeye maruz bırakacak hareketlerden kaçınmalarını ve sulh içinde yaşamalarını emrediyor. Öyle ise, nefsi korumak için, hem ihtiyaçları sağlayabilmek, hem de, harp haline son vermek lâzımdır. Bunun yolu nedir? Hobbes'a göre bunun çaresi, insanların tabiat halinde malik oldukları her şey üzerindeki hudutsuz haklarından, karşılıklı olarak ferağat etmeleridir. Bu da, ancak bir mukavele ile mümkün olabilir. Mukavele, iki veya daha ziyade şahsın haklarından karşılıklı olarak fedakârlıkta bulunmalarıdır. [10] Insanları sulha kavuşturan mukavele olduğuna göre, ahde vefa da bir tabiat kanunudur. Zira, aksi takdirde, mukavelenin hükmü kalmaz ve binnetice tabiat haline dönülmüş ve mücadele tekrar başgöstermiş olur. Hülâsa, tabiat kanunu, başlıca şu üç noktada toplanabilir: I - Insanlar nefislerini korumak için, sulha kavuşmak çarelerini aramalıdır. II - Bu ưourda, tabiat halinde malik oldukları her şey üzerindeki hudutsuz haklarının bir kısmından karşlıklı olarak ferağat etmelidirler. III - Bu karşllkı taahhüde riayet lâzimdur.

Ancak, insanların, tabiat kanunlarına riayet etmemeleri mümkündür. Mantık, onları bu yolda harekete sevketmekle beraber, bazen hislerine kapılarak yakın ve mühim bir menfaatı sulh ve sükûne tercih edebilirler. [11] Binaenaleyh, bu kanunlara uymak üzere, insanların aralarında anlaşmaları lâzımdır. Fakat, sadece anlaşma da kâfi değildir. Tabiat kanununa riayeti mecbur kılmak icap eder. Bunun için, yegâne çare, hiç kimsenin karşı gelmeği göze alamıyacă̆ı kadar kuvvetli bir iktidar tesis etmektir. Bütün insanların, tabiat kanunlarına uygun hareket etmelerini ancak böyle bir iktidar sağliyabilir. Hobbes'a göre, bu derece kuvvetli bir iktidarın vücut bulması için herkesin hak ve salâhiyetlerini bir şahsa veya bir meclise (assemblée) tedavi eylemeleri, yani bütün iradelerin tek bir irade şeklinde tecelli etmesi lâzımdır. Bu şahıs veya meclis umumun mümessili olacak, herkes, iradesini onun iradesine tâbi kılacaktır. Herkesin, böyle, karşılıklı olarak, hak ve halâhiyetlerini, hakikî veya hükmî bir şahsa bırakmaları keyfiyeti bir mukavele ile olur. Hobbes'a göre, insanların birbiriyle akdedecekleri bu mukavelenin formülü şudur: «Kendi kendimi idare etmek için malik olduğum hak ve iktidart, bu sahsa veya bu mec-

[10] Hobbes, De Cive, La liberté II. IX.

[11] Hobbes, De Cive, L'Empire, V. 
lise, bașkalarınin da ayn hak ve iktidarların aynt şahıs veya mec'ise burakmaları sartiyle, devrediyorum?. [12]

॥şte, bu suretie, umumun iradesine sahip olarak teşekkül eden müesse "devlet» ismini alır ki, Hobbes buna, dev, canavar, ejderha mânasına gelen «Léviathan adını veriyor. Demek oluyor ki, devlet: "Insanlartn, sulhu ve müsterek müdafaayt sağlamak için, karşillklt bir mukavele ile, bütün tasarruflarindan umumun iradesini kullanmak salâhiyetine sahip klldiklart hakikî veya hükmî bir sahıstır . [13]

Bütün insaniarın iradelerini devlete tabi kılmaları, herkesin ona mutlak surette itaat etmesi neticesini dogurur. Ve yine, herkesin kendini idare etmek hakkım ona bırakmasi, devletin, tabiat halinde insanların herşey üzerinde malik oldukları hakka sahip bulunmass demektir. Görülüyorki, Hobbes'a göre mutlakiyet, devietin esasinda cevherinde meknuzdur.

Burada müellifin, içtimaî mukaveleden çıardı̆̆ı neticelerin hususiyetlerini belirtmek icap eder:

a) Devletin egemenliğinin menşei insanların aralarında akdettikleri mukaveledir. Ancak, bundan, hiçbir zaman, demokrasi taraftarlarımı iddia ettikleri gibi, egemenliğin esas itibariyle halkta oldư̛̆ neticesini çıkarmamak lâzımdır. Çünkü, Hobbes'a göre tabiat halinde insanlarn arasindaki münasebet sadece bir mücadeleden ibarettir. Vakıa, herkesin kendi canın korumak için mutlak bir iktidarı vardır. Fakat, umumun iradesi olan egemenlik, hiçbir zaman bu şekilde, dałğınık bir halde yaşıyan insanlara atfolunamaz. Bu itibarla egemenlik, devletle birlikte teessüs eden bir bir mefhumdur ve herkesin şahsî iktidarın mukavele mucibince devlete devretmesiyle vücut bulur. Başka bir ifade şekliyle, hükümranlık birçok şahsî iktidarların birleşmesinden husule gelir. Tabiat halinde böyle bir birleşme yoktur. Binnetice egemenlik de mevzuu. bahis olamaz. Devletin teşekkülünden sonra, hukukî bakundan, halk kitlesi yine bir mâna ifade etmez. Çünkü, bu kitleyi teşkil eden insanlar şahsî iktidarlarını devlete bırakmış bulunmaktadırlar. Binaenaleyh, bu vaziyette umumun iradesini yalniz devlet temsil etmektedir. Hülâsa, egemenlik, hiçbir zaman halk kiłlesine ait olmamıştır. Zira, devletten önce, ortada müşterek bir irade zaten yoktur. Devletin vücude gelmesinden sonra da, halk kitlesini tȩ̧-

[12] Holbbes. De Cive. L'Empire, VI, XX.

[1月] Hobles, De Cive, L'Empire V. IX. 
kil eyliyen insanlar, mukavele ile iktidarlarını devlete devretmiş bulunmaktadırlar. Bu itibarla, yine kitle halinde bir mâna ifade etmezler. Onların müşterek iradelerini, yani egemenliği devlet temsil eder.

b) Bundan başka, bu teoride, üzerinde durulması lâzımgelen diğer bir nokta da, mukavelenin, halk kitlesi ile egemen kuvvet arasında de ợil, fakat, insanların kendi aralarında akdedilmiş olmasıdır. Bunlar, karşılıkh olarak, bu suretle vücude gelen egemen kuvvete, yani, muayyen bir şahsa veya meclise itaat etmeği kabul eylemektedirler. Bu itibarla, hükümdar (ister bir şahıs olsun, ister egemenlik bir meclis tarafindan temsil edilsin) mukavelede taraf değildir. Esasen, taraf olmasma da imkân yoktur. Cünkü, mukaveleden önce, ortada egemenlik yoktur. Devletin teşekkülünden sonra ise, iradesini ona devretmiş oldư̆u için, halk kitlesinin hukukî bir mahiyeti olamaz. Bundan iki netice çıkarmak mümkündür. Birincisi, hükümdar bu mukavele ile bağlı deg̛ildir. Ikincisi, insanlar, aralarında akdettikleri bir mukavele ile, yalnız birbirlerine karșı değil, fakat hükümdara karşı da, yani, bir üçüncü şahıs lehinde taahüde girişmiş bulunmaktadırlar. Hobbes bunu bir hibe muamelesine benzetmektedir. Binaenaleyh, halk ne kadar büyük bir çoğunlukla karar verirse versin, hükümdardan, onun rizasi olmadan kudretini geri alamaz [14].

B - Locke: Aynı devirde yetişmiş bir ingiliz müellifi olan Locke da cemiyetin ve devletin esasın mukavele nazariyesine istinat ettirmektedir. Böyle olmakla beraber, Hobbes ile Locke, içtimaî mukaveleden çkardıklan neticeler itibariyle birbirlerinden tamamen ayrihrlar. Hobbes ne derece mutlakiyetçi ise Locke da o derece hürriyetperverdir.

Locke siyasî doktrinini 1690 yılında yayınlanan «Medeni hükûmet hakkında deneme - Essai sur le gouvernement civil adlı eserde açıklamaktadır.

Locke da, başlangıçta insanlarm tabiat halinde yaşadıklarını kabul etmektedir. Ancak, bu müellife göre, tabiat hali, insanların, yalnız ihtiyaçlarını tatmin için hareket ettikleri ve kuvvetin yegâne kanun bulundư̆u vahşi bir devir değildir. Çünkü, tabiat halinde, medeni cemiyetlerin bütün kanunlarına takaddüm eden, onların hepsine üstün olan ve insanların sadece şahsî ihtirasları-

[14] Hobbes, De Cive, L'Empire, Vl, XX. 
na llyarak iş görmelerini önliyen, herkes için mecburi tabiî kanunlar vardir. Muhakeme sahibi bir varlık olan insan bu sayede tabiî kanunları idrâk eder. Bundan başka insan iç̧̧imaî bir varlıktır. Bu itibarla, tabiat halinde dahi münferit yaşama mevzuu bahis değildir. Vakra, tabiat halinde, insanlar hür ve müsavidi:ler. Fakat, hür olmaları, onların istedikleri şekilde hareket etmeleri ve arzulanm her vasıtaya başvurarak tatmin eylemeleri neticesini doğurmaz. Bilâkis, hür ve müsavi olmaları dolayısiyle, tabî̂ kanun, onları, birbirlerinin hürriyetini ihlâl etmekten ve birbirlerini öidürmekten alıkoyar. Bu itibarla, medeni cemiyetin teessüsünden önce, insanlar, "tabiî bir cemiget halinde yaşamaktadı"durlar [15]. Binaenaleyh, Hobbes'in iddia ettiği gibi, tabiat halinde, insanlar arasında mütemadi bir mücadele bahis mevzuu değildir. Tabiat hali, insanların, yer yüzünde, aralarındaki ihtilâfları halletmek salâhiyetini haiz hiç bir üst makama tâbi olmadan, sadece akla uygun bir şekilde yaşamalan demektir. Esasen mücadeleyi, bir kimsenin ya canına kasdedilmesi veya hürriyetinin elinden ahnmak istenmesi doğurur. Bu nevi tecavüzlere ise, tabiat halinde olduğu kadar, medeni cemiyetlerde de mâruz kalınabilir. Meselâ, gece vakti, hırsızlık kasdile bir eve giren bir şahıs, ev sahibiyle boğuşmayı göze almış ve ona kendini müdafaa etmek haḱ$\mathrm{k} ı$ i vermiş olur. Görülüyor $k i$, mücadele, tabiat haline mahsus bir keyfiyet değildir. Bu itibarla, medeni cemiyetlerde olduğu kadar, tabiat halinde de meşru sayılamaz.

Tabiat halinde, insanların bir takım tabiî haklanı vardır. Bunların başında: hayatlarını ve hürriyetlerini müdafaa etmek hakkl gelir. Bunun neticesi olarak, medeni cemiyetlerin teşekkülünden önce, herkes, tabiat kanunlarına aykırı hareket edilmemesine nezaret elmek ve böyle yapanları cezalandırmak hakkın haizdir. Çünkü, bu kanunlara uymamak, bütün beşeriyetin hayatna kasdetmek demektir. Ancak, ceza verilirken, hiddete kapilmamak ve cezanın işlenmis olan suçla mütenasip bulunmasına dikkat etmek gerektir.

Medeni cemiyetlerin teessüsünden evvel, tabiat kanunlarının insanlara bahşettiģ̧ bir diğer hak da mülkiget hakkıdır [16]. Müellife göre, mülkiyet hakkının esası emek dir. Bir insanın vücudunun ve elinin emȩ̌̆i kendi malıdır. Binaenaleyh, emȩ̧i ile veya

[15] Janet, op. cit., c. Il, s. 201.

[16] Janet, op. cit., c. II, s. 202. 
marifeti sayesinde, tabiatten istihsal edebildigi her şey ona aittir. Demek oluyor ki, insanlar, tabiat halinde herkese müşterek olan mallan elde etmek için emek verdikleri takdirde, şahsi mülk haline getirebilirler. Meselâ, tabiat halinde, ağacının dalında duran bir yemiş herkese aittir. Fakat, eğer bir kimse onu dalından koparmak için bir emek sarfederse, yemiş o kimsenin şahsi malı olur. Çünkü, sözü geçen şahıs, yemişe malik olmak için onu koparmak zahmetine katlanmıştır [17].

Nihayet, medeni cemiyetlerin teessüsünden önce, tabiat kanunlarının insanlara tanıdığı sonuncu hak: babanın focuğu üzerindeki iktidartdır. Ancak, evvelâ, bu iktidar, aile içinde, baba ile ana arasında paylaşımıştır. Bundan başka, babalık iktidarı hudutsuz değildir. Yani, esirin efendisine ait olduğu gibi, çocuk da babasının malı telâkki edilernez. Babalık iktidarı, çocuğa tahakküm etmeğe vesile olmamalı fakat, onu korumağa yaramalıdır. Çocuğun velâyet altında bulunmasının sebebi, kendini müdafaa etmekten âciz olması ve cehaletidir. Baba, onu himaye edecek, büyütecek, hür olan ve hürriyetini müdafaa edebilen bir insan yapacaktır. Hürriyet, muhakemeye istinat eder. Binaenaleyh, çocuk, tabiî veya medeni kanunları muhakemesiyle idrâk edebilecek ça-

[17] Locke'dan önce mülkiyetten bahseden mäellifler, bu müessesenin esasmı işgal veya kanuv olarak göstermişlerdi. Emeğin, mülkiyete esas teşkil edebilecę̆ine, P. Janet ye göre, illk defa, bu filozof ileri sürmüştür. (Cilt ll, s. 203) Locke'a göre, gayrı menkul mülkiyetini iktisap için aynı kaide caridir. Yani bir insan çalışarak müşterek topraklardan ne kadarını sürüp ekebilirse o kadarına sahip olur. Bunun için, diłger insaoların rizaların istihsal etmeğe lüzum yoktur. Çünkü, tabiat, insaolara, yaşayabilmek için çalışmak meeburiyetini yüklemekle, fiilen (ipso facto) onlara, emeklerile kıymetlendirdikleri şeyler üzerinde, mülkiyet hakkını tanımış demektir. Esasen, bir şeyiı değeri, ona verilen emekle mütenasiptir. (görülï̌yor ki, değerin esasının emek olduğunu A. Smith'den önce, Lacke jddia etmiştir.) Locke mülkiyet hakkıos iki sekilde tahdit etmektedir. Ona göre emek sayesinde bir malın mülkiyetiui elde etmek için: I - ayn maldạ ve onun kadar iyi olandan başkaları için de bulunması lâzımdır. Il - O maIdan ihtiyaçtan fazla almamış olmak icap eder. Bu nazariyeoin çürük tarafları yok deçildir. Bilhassa toprak mülkiyetini iktisap için, ełer diğer kimselerde aynı cins topraklar. dan kalması şart koşulursa fỉliyatta hiç kimsenin arazi sahibi olmaması lâzınıgelir. Çünkü, iyi cins toprakların ahalinin miktarile mütenssip bir derecede vasi oldukiarı kabul edilse bile bunların uzaklıkları, sarp mıntakalarda bulunmaları aralarında bir rant farkı doğurur. Bununla beraber, bu nazariyede, üzerinde dikkatle durulması lâzım gelen cibet, mülkiyetin bir emek mahsulü telâkki edilmesi ve onun tabîi bir hak, yani cemiyetten ve kanundan önce meveut bulanan bir hak olarak tauınmasıdır. 
ğa gelince, hürriyetine sahip olur; ve babanın velâyeti sona erer. Diłger taraftan, babalık iktidarı, gayesine uygun bir şekilde kullanıldığı takdirde muteberdir. Çocuğunu ihmal eden, ona fena muamelede bulunan bir baba velâyet hakkından mahrum kalır. Hakikatte, babalik otoritesi bir hak olmaktan ziyade bir vazifedir.

Görülüyor ki, tabiat halinde, bir insanın diğer bir insan üzerinde tahakkümü gibi görünen babalık iktidarı da, hakikatte, insanların hürriyetlerinin săglamağa yarayan bir vazifeden ibarettir. O halde, tabiat halinde insanlar tamamen hür ve müsavidirler. Hayatlarm, hürriyetlerini müdafaa etmek ve emeklerine mukabil müIkiyete sahip olmak haklarına maliktirler. Hiç kimsenin diğer bir kimseye tahakküme salâhiyeti yoktur. Bilâkis, herkes birbirinin hakkına riayetkâr olmakla mükelleftir.

Eğer, insanların bir kısmı kötülük yapmak istidadında olmasalar ve diğer bir kısmı da, kendilerini müdafaa edemiyecek kadar zàyf bulunmasalard, tabiat hali ilânihaye sürebilir ve ikincilerin birincilere karşı korunması için bir takım tedbirlerin alınması gerekmezdi. Medenî cemiyetler, herkesin tabiat kanunlarına riayetini sağlamak maksadiyle tesis edilmişlerdir.

Medenî yahut siyasî cemiyetler, tabiat halinde, herkesin ayrı ayrı malik bulunduğu, tabiat kanunlarına riayet etmiyenleri cezalandırmak hakkından, topluluk lehine feragat eylemeleriyle vücut bulur [18]. Burada, Hobbes ile Locke'un nazariyeleri arasindaki fark daha mütebarizdir. Filhakika Hobbes'a göre, insanlar, siyasî cemiyeti, yani devleti kurarken, ona hemen bütün haklarını terketmişierdir. Binaenaleyh, cemiyet halinde, ancak, hükümran kuvvetin, yani $r$ süspet hukukun, kendilerine bahşettiği haklara sahiptirler. Halbuki, Locke, siyasî cemiyet tesis olunurken, insanların, bütün haklarından değil, sadece cezalandırmak, kendi başlarına adaleti yerine getirmek hakkından feragat etmiş ve yalntz bu hakkı devlete bırakmış bulunduklarmı ileri sürmektedir. Böyle bir cemiyetin vücude getirilmesi için umumun rızası lâzımdır. Çünkü insanlar, esas itibariyle müstakildirler ve onların herhangi bir üsŁün otoriteye tâbi tutulabilmeleri için, buna bizzat muvafakat etmeleri şarttır. Umumun muvafakati elde edilemediği takdirde, siyasî cemiyet mevzu bahis olamaz. Yainız, bu muvafakat, sarih olabileceği gibi zımnî de olabilir. Diğer bir söyleyiş şekliyle, si

[18] Locke, İtimaî tnukaveleyi tarihî bir vaka olarak kalưl eder. Bk. Jel linek, op. cit., c. I, s. 334 . 
yasî cemiyetin tesisi için herkesin ayrı ayrı 've sarahaten buna razı olduklarını bildirmeleri lâzımgelmez. Bir kimsenin yaşadıł̆ı memleketin kanunlarma ve devlet reisine itaat etmesiyle, onlardan himaye ve muavenet istemesiyle, siyasî otoriteye tâbi bulundư̛̆una dair, zımnen rızası hasıl olmus sayılır.

Demek oluyor ki, devlet bir mukavele ile vücude gelmiştir, ona tanınmış olan egemenlił̧in bir gayesi vardır. Bu gaye, hususî şahısların haklarının korunmasıdır. Eğer devlet. hükümranlı̆̆ını bu gayeye aykın bir şekilde kullanırsa, mukaveleye riayet etmemiş olur. Bu takdirde, halk da ona itaatle mükellef değildir ve tabiat halindeki bütün hürriyetlerini yeniden iktisabeder [19]. Lock'a göre, içtimaî mukavele, devlet ile idare edilenlere karşıllklı mükellefiyetler yüklemektedir. Şayet egemenliợi istimal mevkiinde olanlar, bu iktidarın gayesine uygun hareket etmezlerse, idare edilenlerden itaat beklemeð̌e haklar yoktur.

Siyasî iktidarın vücude gelmesini vatandaşların rızalarına istinat ettirmekle, Locke, halkın iradesinin her şeye üstün olduğu, yani egemenliğin millette bulunduŏu neticesine varıyor. Binaenaleyh, halkm ne kadar büyük bir ekseriyetine dayanırsa bir hükûmetin o nispette meşruiyeti artar. Bundan başka, devletin, muayyen bir gayenin tahakkuku için tesis edilmiş bulunduğunu ileri sürmek, egemenliğin, ancak bu ư̆urda kullanılabileceł̆ini kabul etmek demektir. Başka bir söyleyiş şekliyle, devletin kudreti mutlak değildir. $\mathrm{O}$, bu üstün otoriteyi ancak insanların haklarını korumak için kullanabilir ve kullanmahdur.

C - Grotius ve diğer müellifler: Grotius de Aristo gibi, insanların yaradilışları iktizası içtimaî bir mahlûk olduklarını kabul etmektedir. Onların, cemiyet hayatından bekledikleri nizam ve sükûndur [20]. Daha küçük yaştan, insanlarda içtimaîlik duygusu etraflarını memnun etmeğe çalışmak, başkalarının dertleriyle alâkadar olmak şeklinde kendilerini belli eder. Bilâhara bu içgüdüye uymă̆ı muhakeme de emreder. Grotius'e göre de siyasî cemiyetin esasını içtimaî mukavelede aramak lâzımdır. Ancak, müellif sharp ve sulh hukuku hakkında - De jure belli ac pacis" adh eserinde, içtimaî mukaveleyi diğer müellifler gibi, mücerret bir fikir, bir faraziye, düzenleyici bir prensip olarak değil, fakat ta.

[19] Janet, op. eit., C. II, S. $213-215$ ve Mosca, Histoire des doctrines p otitiques, Paris 1936, S. 197 .

[20] De Lapradelle, Maîtres et doctrines, Cours de doctorat, Paris, 1939. 
rihî bir vakıa olarak kabul etmektedir. Bu itibarla, Grotius'e göre bütün insanlk camiasına şâmil, bir tek içtimâ̂ mukavele değil. fakat, ne kadar müstakil siyasî teşkilât varsa o miktarda ayn ayrı içtimaî mukaveleler vardır. Binaenaleyh, fiilen mevcut būtün devletler ve bütün hükûmet şekilleri, böyle bir içtimâ̂ mukaveleye istinat ettiklerinden meşrudurlar. Şüphesiz, insanlan bir arada yaşamađ̆a sevkeden içtimaîlik duygusu tabiat vergisidir ve bütūn insaniyete müşterek bir histir. Fakat, bu, bütün içtimaî mukavelelerin, birbirleriyle eş olduklarını ispat etmez. Çünkü, bunların hepsi aynı şartlar altında akdolunmamıştır. Değişik fiilî vaziyetlere göre yapılmış olan mukaveleler muhteva itibariyle birbirlerine benzemiyebilirler. $O$ halde, Grotius'e göre halkn egemen kuvete daima itaat etmek mecburiyeti vardir.

XVII nci yüz yılın diğer müelliflerinin içtimaî mukavelelerinin orijinal tarafları olmadı̆̆ için bunların üzerinde uzun boylu durmayacał̆ı [21]. Bunlardan Spinoza'nın teorisi aşağı yukarı Hobbes'ınkini hatırlatmaktadır [22]. Spinoza'ya göre başlangıçta bir tabiat hali mevzuu bahistir. Tabiat halinde, insanların haklarmm hududu iktidarlarının sınırı ile tâyin edilmiştir. Yani kuvvet, haḳtır. Bu hal mücadeleye sebep olur. Insanlar, bu mücadeleye son vermek için, içtimaî mukaveleyi akdederek, bütün haklarından topluluk lehine feragat eylemişlerdir. Ancak, Sipinoza devletin gayesinin insanların hürriyetlerinin korunması olduğunu ve devlef bu gayeye aykırı harekette bulunduŏu takdirde içtimaî mukavelelerinin bozulacă̆ını tasrih etmektedir.

Puffendorf, içtimaî mukaveleyi, fena insanlardan duyulan korkuya istinat ettirmektedir [23]. Bossuet'ye gelince "Mukaddes kjtaptan istihraç edilmiş siyaset - Politique tirée de l'Ecriture Sainte adlı eserinde, insarların kötü ihtiraslarının medenî bir cemiyeti zaruri kıldı̆̆ından, medenî cemiyetin de bütün iktidarı hükümdarın elinde toplyyan bir mukavele ile vücut bulduğundan bahsetmektedir.

XVIll inci yüz yıla geldiğimizde, içtimaî mukavele nazariyesinin, yine birçok belli başlı filozoflar tarafından benimsenıniş

[21] Tafsilât için bak : Okandan, op. cit., s. 86 ve : devamı.

[ษ2] B. de Villeneuve, Traité général de l'Etat, Paris 1929, eilt I. s. 45.

[93] Puffendorf'a göre birçok mukavele mevzuu ha'histir. İlk önce insanlar bir birlik mukavelesi ile millet baline gelirler. Sonra bir diger mukavele ile devlet §̧eklini tesbit ederler. Nihayet bir üçüncä mukavele ile hïkümdarı tayin ederler. Jellinek, op. cit. C. 1. S. 334 . 
oldư̆unu görürüz. Ezcümle David Hume (1711 - 1776), Jean - Jacques Rousseau (1712-1778), Holbach (1723-1789), Emmanuel Kant $(1724-1804$ ! ve J. G. Fichte $(1762-1814)$ bunlar meyanındadir.

J. J. Roussean : ancak, bütün bu müellifler arasında, içtimaî mukavele nazariyesini en fazla tekâmül ettiren Rousseau olmuştur. O kadarki, bugün dahi bu nazariyeden bahsedildiği zaman ilk hatıra gelen Fransız filozofu olmaktadır.

J. J. Rousseau'nun içtimaî mukavele nazariyesi hakkında tam bir fikir edinebilmek için onun: "Insanlar arasındaki müsavatsızlığının menşei hakkında izahat-Discours sur l'origine de I'inégalité parmi les hommes" ve "Içtimaî mukavele-Contral social * adlı eserlerini incelemek lâzımdır.

Umumiyet itibariyle kötümser bir eser olan birincisinde, müellif, uzun uzadıya tabiat hali üzerinde durmakta ve cemiyetin teşekkülünden önceki insanlar hakkında izahat vermektedir.

Rousseau stabiat hali * ni bir nevi vahşet hali olarak tahayyül etmektedir. Bu devirde insanın diğer hayvanlardan fizik bakımdan hemen hiç farkı yoktur. «Bazılarına nisbeten daha kuvvetsiz, bazılarından da daha az çevik, fakat dikkat edilecek olursa hepsinden daha becerikli s yegâne kaygusu karnını doyurmak, susuzluğunu gidermek ve istirahat edebileceği emin bir yer temin eyliyebilmekten ibaret, ürkek ve kurnaz bir hayvan. Manevî bakımdan ise, insanı hayvandan ayıran iki hususiyet vardır. Birincisi hayvantn tabiat kanunlarma içgüdüsü ile tâbi bulunmasina mukabil insan faaliyetlerinde ihtiyarna, yani menfaatine, en uygun olacak şekli seçmek hususunda serbestisine sahiptir. Saniyen, insanda tekâmül edebilmek vasfı mevcuttur. [24]

Tabiat halindeki insanlarda ahlâk mefhumu yoktur. Binaenaleyh onlar için iyi ve kötü mevzuubahis olamaz. Birbirlerine karşı vazifeleri bulunmadı̆̆nndan mesuliyetleri.de yoktur. Nihayet, bu devirde insanlar son derece iptidaî olduklarından aralarındaki müsavatsızlıklar da o nisbette azdır. Esasen, birbirleriyle çok seyrek münasebette bulunduklarından, mevcut cüz'î müsavatsızlıkların dahi farkına varılmaz.

Insanlarin tabiat halindeki bu müsaviliğini bozan, mülkiyet ve ziraatle, madenleri işlemek usulünün (métallurgie) keşfedilmesi

[24] Rousseau, Discours sur l'inégalité, Première partie. 
olmuştur. Rousseau'ya göre: «bir tarlanın etrafın çille çevirip: burası bana aittir, diyen ve bu söze inanacak kadar saf kimseler bulan ilk insan medenî cemiyetin hakikî kurucusu olmuştur. [25] Mülkiyet müessesesinin meydana çıkması, müthiş bir mücadele hali yaratmıştır. Bu mücadeleden, zenginler, zenginlikleri yüzün. den fakirlerden daha fazla müteessir olduklarından ve kuvvet sayesinde elde ettikler servetlerinin, yine kuvvet yolu ile elden çlkabileceğini düşündüklerinden bu hale bir son vermek çarelerini aramışlardır. Zengin, ihtiyaç saikasiyle, nihayet, insan aklının bulabileceği en münasip çareyi keşfetmiş ve kendisine taarruz edenlerin kuvvetlerini kendi nam ve hesabına kullanmak, hasımların kendi müdafileri şekline sokmak, onlara başka kaideler telkin ederek, bașka müesseseler kabul etınelerini sağhyarak kendi menfaatine aykırı olan tabiat karıununun tazyikından kurtulmak yolunu tutmuştur. «Bu maksatla, komşularma, onları birbirine düşüren, mâlik oldukları șeylerin muhafazasını yeni bir ibtiyacın temini kadar pahalıya mal eden ve hiç kimsenin ne fakirlikte ve ne de zenginlikte emniyete kavuşmadıŏı bu vaziyetin fecaatini izah ettikten sonra, kendi fikrini kabul ettirmek için lâzımgelen sebepleri de kolayca buldu ve dediki : zayıfları tazyikten kurtarmak, muhterisleri zaptedebilmek ve herkese kendine ait șeyler üzerindeki mülkiyetini sağhyabilmek için birleşelim, herkesin bilâ istisna uymatga mecbur olacağı ve hem kuvvetliye ve hem de zayıfa karş̧lıkh vazifeler yükliyerek tâliin cilvelerini tashih edecek âdalet ve selâmet kaideleri koyalım. Bir kelime ile, kuvvetlerimizi birbirimize yöneltecek yerde, onlan bir araya getirerek, bizi âdil kanunlara göre idare edecek, topiuluğun bütün âzasını himaye ve müdafaa eyliyecek, müşterek düşmanları kovacak ve cümlemizi yeni bir uzlaşma halinde tutacak üstün bir kudret haline sokalım.?

«Kaba, kolay inandırlır, esasen hakemden vazgeçemiyecek kadar aralannda halledecek işleri çok olan ve lüzumundan fazla cimri ve muhteris olduklan için uzun müddet bir efendiye ihtiyaç duymadan kalamıyacak insanları, sürükliyebilmek için, buna muadil sözlerin daha azı da kâfi geldi. Herkes, hürriyetini sağłıyacăgı zebabiyle zincirlerine doğru koştu. Çünkü, bunlar, bir siyasî teşekkülün faydalarım anlıyacak kadar muhakemeye sahip olmakla beraber, böyle bir şeyin tehlikelerini sezecek derecede tecrübeye

[25] Rousseau. Discours sur l'inégalité, Seconde partie 
mâlik dẹ̛̆ildiler. Içlerinden kötülükleri evvelden görebilecek kadar kabiliyetli bulunanları ise, esasen, bu vaziyetten istifade etmeğ̀i düşünenlerdi. Hattâ hâkim olanlar bile, bir yaralınin hayatını kurtarmak üzere kolunu kestirmesi gibi, hürriyetlerinden bir kısmını korumak için diğer bir kısmını fedaya rıza göstermenin lâzımgeldiọ̆i kanaatine vardılar.

¿Işte, zayıflara yeni köstekler vuran, zenginlere yeni bir kudret bahşeden, tabjî hürriyeti bir daha geri gelmiyecek şekilde ortadan kaldıran, mülkiyet ve müsavatszzlık esasımı ebediyen kuran, ustalıkla yapılmış bir gasptan bir daha geri alınmaz bir hak yaratan ve birkaç muhterisin menfaati ư̆runa, bundan böyle bütün insanlığı çalışmăga, kölelił̆ge ve sefalete mahkûm eden cemiyetin ve kanunların menşei budur veya böyle olmalıdır.> [26]

Görülüyor ki, Rousseau'nun «Insanların müsavatsızlıklarmın menşei adlı kitabında ileri sürdüğ̈ eiçtimaì mukavele» şekli çok kötümser düşüncelerin tesiri altında kalınarak ileri sürülmüştür. Buna göre, cemiyetin menşei, zenginlerin, can ve mallarımı muhafaza edebilmeleri için, fakirleri, birtakım parlak sözlerle kandırarak onları kendilerine hizmete ve kendílerini müdafaaya adetâ mahkûm etmelerinden başka birşey değildir. Müellif, cemiyete karşı küskünlüğünï o dereceye vardırmıştır ki, haklıyı haksızla bir tutmakta, gasp suretiyle elde edilen mülkiyetle emek mahsulü olan mülkiyet, tabî̂ hürriyetin ma'kul hudutlan ile bu hürriyetin gayn âdilâne bì şekilde tahdit olunması, idare ile istibdat, arasında hiçbir fark gözetmemektedir. Insanlara gelince, onlar da ya fena ruhlu kimselerdir veya budaladirlar. [27]

Ancak, müellifin "Içtimaî mukavele» adh eserinde, bu husustaki fikirlerinin tamamiyle değişmiş olduğunu görüyoruz. Filhakika, Rousseau, bu ikinci kitabda, içtimaî mukavelenin sebeplerini bize bambaşka bir şekilde izah etmektedir. Burada, artık, zenginler tarafından fakirler aleyhine yapıImıs suikasttan bahis yoktur. [28] Tabiat halinde iptidaî olduklarından ihtiyaçları da o nisbette az ve kolay tatmin edilebilir olan insanlar gitgide tekâmül etmişlerdir. Tekâmül mülkiyeti, mülkiyet de mücadeleyi dogurmuştur. Bu mücadeleyi önlemek için, kuvvetin yerine hakkı koymak lâzımdır. Çünkü, kuvvet fiziki bir iktidardır. Ona boyun

[26] Rossean, op. eit. Seconde partie

[27] Janet, op. cit., C. II, S. 422.

[28] B. de Villeneuve, op. eit. s. 48. 
ełgmek aslâ iradî bir fiil, bir vazife olamaz. Kuvvetin bir hak kaynał̆ı olduğu bir an için kabul edilse bile, bu, devaml bir hak yaratamaz. Çünkü bu kuvvete üstün diğer bir kuvvet birincinin hakkına da tesahüp edebilecektir. Eger zorja itaat icap ediyorsa, itaatı bir vazife telâkki etmeğge lüzum yoktur. Insanın itaata zorlanmadı̆̆ı zaman itaat etmek için mânevî bir mecburiyeti mevcut değildir, [29] Görülüyor ki, kuvvet hak olamaz ve hiçbir insanın bir diğeri üzerinde tabî̂ bir iktidarı yoktur. $O$ halde mücadele haline nihayet vermek için kuvvete değil meşru vasıtalara müracaat lâzımdır. Iktidarı, ancak, içtimaî mukavele meşru kılar. \$u kadar ki, mukavele ile insanlar, tabiat halinde malik oldukları bütün haklardan vazgeçemezler. Çünkü, sadece sükûnet ve rahatın hiçbir kıymeti yoktur, insan hapishanedeki hücresinde de sükûnet içindedir. Hürriyetinden ferağat, insanlık sıfatından, insanlık haklarından ve hattâ vazifelerinden vazgeçmek demek olur. Oyle bir birleşme şekli bulmalı ki, her âzanın canını ve malların müşterek kuvvet vasitasiyle müdafaa ve himaye etsin ve herkes herkesle birleșmekle beraber yine kendi kendine itaat etsin ve binaenaleyh eskiden olduơ̆u kadar hür kalsın. Rousseau'ya göre, böyle bir mukavelenin bütün hükümleri bir tek hükme irca edilebilir : Her âzanın, bütün haklariyle beraber kendini toplulư̆ga devretmesi. Bu suretle, herkes, aynı şekilde kendini cemiyete terkettiğinden, herkes için şart aynıdır ve herkes kendini herkese terkettiģinden, neticede hiç kimseye terketmemiş oluyor. Hülâsa sherbirimiz, umumî iradenin güksek idaresi altında nefsimizi ve bütün iktidarımizi birlestiriyoruz ve her âza bütünün ayrllmaz bir parçast olugor.

Böyle olunca, bu birleşme fiili ile, her âkidin hususî şahsı yerine, heyetteki rey adedi kadar âzadan mürekkep hükmî ve müşterek bir varlık yaradılmıs oluyor. Bu varlık, yine aynı fiilden, vahdetini, müşterek benliğini, hayatını ve iradesini iktisap etmiş oluyor. Diğer bütün şahısların birleşmelerinden vücude gelen bu kamu şahsı eskiden Cité ismini alırdı. Bugün ise âzaları, ona, passif oldư̆u zaman devlet, faaliyette bulunduğu zaman hükümdar ve benzerleriyle mukayese olundưu zaman iktidar (puissance) adını veriyorlar. Âzalara gelince, bunlar müştereken halk ismini almakta ve tek başlarına egemen otoriteye katılmaları bakımından vatandaş, devletin kanunlarına tâbi olmaları

[29] Rousseav, Contrat social, L. 1. ch. IIf. 
bakımından ise tebaa adı ile anılmaktadırlar. [30] Rousseau'ya göre "bu içtimaî mukavele, mahiyeti itibariyle, oy birliẓ̆i ile kabul edilmesi icap eden yegâne kanundur » mukaveleye muarız olanlar ondan hariç bırakılırıar ve vatandaşların yanı başında yabancı sifatını iktisap ederler. Devlet teessüs ettikten sonra, mukaveleyi kabul etmek için, onun ülkesinde ikamet kâfidir.

Isşte bu suretle meydana çıkan müşterek kuvvet: umumî ira dedir. Müellif, bu umumî irade mefhumu sayesinde, vatandașların hürriyet ve ferdî haklarının muhafaza olunabileceł̧ini ileri sürmektedir. Pratik bakımdan, umumî irade ekseriyetin iradesiyle müteradiftir.

Netice itibariyle, Rousseau'nun "Içtimaî mukaveles adlı eserinde müdafaa ettiği tezi şu suretle ifade etmek mümkündür: bir taraftan insanları hürriyetlerinden, velev kendi arzulariyle dahi olsa mahrum etmek imkânsızdır. Dǐ̆er taraftan, mücadele haline nihayet verip cemiyet halinin teessüsü için hâkim bir otoriteye insanların tâbi olmaları. yani hürriyetlerinden fedakârlıkta bulunmaları gerekmektedir. Bu çıkmazdan kurtulmanın yegâne çaresi, müellife göre, bu cemiyetin âzası olan herkesin karşılıklı olarak bütün hak ve hürriyetlerinden topluluk lehine. vazgeçmeleridir. Bu suretle, ortaya çıkan ve hususî iradelerin birleşmesinden vücude gelen müşterek irade bir tüzel kişidir. Herkes bu tüzel kişiye itaat edecek ve bu suretle cemiyetin düzeni kurulmuss olacaktır. Ancak, umumî irade, aynı zamanda, bu cemiyetin âzası bulunan herkesin hususî iradesinin de ihtiva ettiginden insan ona itaatle kendi kendine itaat etmiş olacak ve bu suretle hürriyetinden de hiçbir fedakârhk yapmamış bulunacaktır [31]. Esasen fertlerin tabiî haklarını devlete bırakmalarına mukabil devlet onlara medenì hakları bahşedecek ve bu suretle, insanlar, mukaveleden evvel sahip oldukları teminatsız tabî̀ haklara karşı, siyasî cemiyet teessüs ettikten sonra, devlet tarafından teminat altına alınmış medenî haklar edineceklerdir. Binaenaleyh, içtimaî mukavelede kayıp yok bilâkis kazanç vardir.

Rousseau, devletin menşeini içtimaî mukaveleye istinat ettiren müelliflerin sonuncusu değildir. Cenevreli filozoftan sonra da birçokları içtimaî mukavele nazariyesini benimsemişler ve türlü izahların yapmışlardır. Bunların hepsinin üzerinde ayrı ayrı

[30] Rousseav, Contrant L. I ch. VI.

[31] Jellinek, op. cit., e. I, s.336. 
durmağa her birinin arzettiọ̆i hususiyetleri açiklamağa burada lüzum yoktur. Bunların içinden en meşhuru, kafalarda en fazla yeretmiş veya iz bırakmış olan, hiç şüphe yoktur ki Rousseau'nunkidir. Bu itibarlaî içtimaî mukavele hakkında hükmümüzü verirken, daha ziyade bu müellifin izah tarzını gözönünde bu* lunduracağız.

İçtimầ mukavele nazar yesinin tenkidi. - Içtimai mukavele nazariyesi hakkındá tam mânasiyle bir hükme varabilmek için bu nazariyenin muhtelif iki telâkkisini birbirinden ayırdetmek lâzımdır.

Bunlardan bírincisi, içtimaî mukaveleyi tarihî bir vakıa olarak kabul edenlerin telâkkisidir. Filhakika bunlar çok eski devirlerde böyle bir anlaşma hádisesinin hakikaten vukua geidiğini ve bundan önce de insanların gerçekten tatiat halinde bulunduklarını iddia ederler. Hattâ, yukarıda da gördüğümüz veçhile, Grotius, daha ileri vararak, her devletin ayrı bir mukaveleye istinet ettiğini ileri sürmektedir.

Içtimaî mukavelenin bu tariĥ́ telấkkisi, zamanımızda ilmî kıymet ve ehemmiyetini tamamen kaybetmiş bulunmaktadır [32]. Zira, insanların, pek eski devirlerde dahi, tabiat halinde yaşamış oldukları, gerek sosyolojide, gerek tarihte ispat edilmiş olmaktan uzaktır. Tarihin erişebildiği en eski devirlerle dahi insanlar cemiyet halinde yaşamakta idiler. Insanın, kısa veya uzun bir zaman zarfında cemiyet dışında yaşadığını kabul etmek, adetầ onun fiziki hayatı için lüzumlu olan melekelerinden birinden mahrum bulunarak yaşayabilmiş olduğuna inanmak kadar mantığa aykırıdır [33]. Gerek Antropoloji, gerekse Etnografya tetkiklerine göre, insan, mevcudiyetini idrak ettiği andan itibaren cemiyet içinde yaşamıştır ve onun için, içtimaîlik iç güdüsü de gözönünde tutulursa, ancak bu şekilde bir hayat mevzuu bahis olabilir [34].

Bizzat içtimaî mukavele hâdisesine gelincẹ: eğer bu, hakikaten tarihî bir vakıa olsaydı, bu derece mühim bir hâdiseye dair, hiçbir tarihî vesikanın zamanımıza intikal etmemiş bulunması, hattâ muhtelif milletlerin efsanelerinde dahi bu hususa dair

[32] Jellinek, op. eit. C. I, S. 338.

[33] B. de Villeneuve, op. cit. C. I. S, 54.

[34] R. Okandan, op. cit., s. 133. (Tarihten ônceki cilâlı tą̊ devrinde münferit halin bulunduğuna dair Bk. aynı eser, s. 134). 
hiçbir işarete rastlanmaması mümkün olur muydu? Bundan başka, bütün milletler, aşał̆ı yukan aynı esaslara göre bu mukaveleyi yapacaklarına nazaran zamanımızdaki siyasî müesseselerin birbirlerinden bu derece farklı olmaları nasil açıklanabilir. Sonra, böyle bir mukavelenin vücut bulması için bütün insanların bu hususta tam mânasiyle ittifak etmiş olmaları lâzımdır. Böyle mühim bir kararda istisnaların bulunmayışını tasavvur etmek de imkânsızdır. Nihayet, içtimaî mukavelenin akdolunabilmesi için, tabiat halinde insanların hakikaten birbirleriyle müsavi olması gerekir. Halbuki, tabiat hali kuvvetin hâkim olduğu bir mücadele devridir. Böyle bir devirde müsavattan nasıl bahsolunabilir [35].

Hülâsa, içtimaî mukavelenin tarihî bir vakıa olarak ileri sürülmesi hiç bir suretle kabul edilmeğe, hattâ üzerinde durulmă̆a değer mahiyette değildir. Ancak bu telâkkiyi red ve cerh etmekle içtimaî mukavele nazariyesini tamamen bertaraf etmek mümkün deŏildir. Çünkü, bizzat Rousseau ve Kant da dahil olmak üzere bir çok müellifler bu nazariyeyi tarihî bir vakıa olarak deł̆il bir faraziye, düzenleyici bir' prensip olarak kabul etmektedirler. Filhakika, meselâ Rousseau «insanların arasındaki müsavatsızlıkların menşei hakkında izahat * adh eserinde bu ciheti sarahaten belirtmekte ve «bu mevzua girmek için yapilan araştırmalan tarihî hakikatler olarak kabul etmemek fakat onları sadece, hâdiselerin hakiki menşeini göstermekten ziyade mahiyetlerini aydınlatmak üzere yapılmış farazi ve şarta baŏlı bir muhakeme silsilesi olarak ele almak lâzımdır» demektedir [36]. Yine Rousseau, tabiat ha* linden bahsederken, böyle bir halin artık mevcut olmadığını, belki de hiç mevcut olmamis bulunduğunu, ihtimalki ileride de mevcut olmıyacağını belirtmekte, fakat, böyle olmakla beraber hali hazırdaki vaziyetimiz hususunda doğru bir fikir edinebilmemiz için, tabiat hali hakkında dợru malûmata sahip bulunmamız lâzımgeldiğini ilâve etmektedir. $\mathrm{O}$ halde, mevzuu bahis olan hakiki tarih değil, farazi bir tarihtir. Yani, maksat, hâdiselerin hakikatte nası olduklarını dȩ̧̛il fakat nasıl olması lâzımgeldił̧ini izahtan ibarettir. Rousseau, Insanların arasındaki müsavasızhk... adlı eserinde, hâlen mevcut bulunan siyasî ve iktisadî müsavatsızlık ve imtiyaz rejiminin insanın yaradılışına aykırı, keyfî ve binaenaleyh gayrı âdil bir şey olduğunu ispat etmek istemiştir. (lçtimaî mu-

[35] B* de Villeneuve, op. cit., C. l, S. $\because 4$.

[36] Discours sur l'inégalité, Başlạugı̧̧. 
kavele) nin ilk cümlesi olan : ‘nsanlar hür olarak doğmuştur, fakat her tarafta zincirler içindedir"sözü ilk eserdeki fikri tam mânasiyle hülâsa etmektedir [37]. Müellifin klçtimaî mukaveles isimli kitabındaki ana fikir ise, insanları sun'î bir şekilde birleştiren ve esaslarını tabiî nizamın prensiplerine dayanan bir cemiyet şekli tâyin etmek, devleti, sinesindeki insanların aslen sahip oldukları hakların tamamiyetini koruyacak şekilde kurmak, hürriyet ve müsavata içtimaî bir temel ve siyasî bir müeyyide temin eımek ve köklerini tabiattan aldıkların belirterek bu hakların cemiyete ve devlete tekaddüm ettiğini ortaya koymakhır [38].

Kant da, içtimaî mukavelenin tarihî bir vakıa olmadığını bunun akıl ve muhakemenin mahsulü olan bir fikirden ibaret bulundư̆unu, ancak hukuk devletinin mevcudiyeti için insanların birleşerek bir mukavele ile devleti vücude getirdiklerinin kabul edilmesi lâzımgeldiğini belirtmiştir. [39]. Keza, Fichte de, böyle bir mukavelenin hakikatte mevcut bulunmadığına ve bunun sadece bir faraziye teşkil eylediğine açık bir tarzda işaret etmiştir.

Hülâsa bu telâkkiye göre, içtimaî mukavele şe'nî bir hâdise değil aklın bir emridir.

Devletin menşeini içtimaî mukavelede bulan nazariyenin bu ikinci şekli de, kabule şayan değildir. Çünkü, evvelâ inşa tekniği bakkımından mahzurludur ve devleti iradî bir fiile istinat ettirmekle onun temelini çürütmektedir. Saniyen, mantıki olmaktan uzak ve tezatlarla doludur.

Filhakika, içtimaî mukaveleye göre, devletin esasi, vatandaşrın muvafakatlarına dayanır. Ancak, devletin istikrarın sağlıyabilmek için, bu muvafakatın bir kere izhar edildi mi bir daha geri alınamıyacağını ispat etmek lâzımdır. Çünküu, aksi takdirde, siyasî cemiyet, âzalarm her an fikir değiştirebilecekleri nazarı itibara alnnacak olursa, mütemadi bir da ğılma, bir çözülme tehlikesine maruzdur. Insan tabiati iktizası hür olduğuna göre bu hürriyetine istinaden her zaman mukaveleyi feshedebilmek hakkını haiz bulunacaktır, Böyle olunca, mukaveleyi fesheden insan, artık mukavele dışi addolunacak, devletten hiç bir hak dermeyan edemiyecek fakat buna mukabil devletin de o şahıı üzerinde hiç bir

[37] Del Vecenio, Justice - droit - Etat, Paris 1938, s. $259-2611$.

[38] Del Vecchio: Justice - Droit - Etat, s. 261 .

[39] Emmanuel Kant, Principes metaphysiques du droit, Paris 1858, s. 179.

[40] Okandan, op. eit., s. 137. 
hakkı kalmıyacaktır. Bir kişinin yapabildiği bu işi bir çok kimselerin birden yapamamaları için hiç bir sebep yoktur. Hattâ, bu kimseler, isterlerse, birleşerek arzu ettikleri hükümleri ihtiva eden yeni bir mukavele yapıp yeni bir devlet tesis eyleyebilirler. $O$ halde, devletin çözülmesine mâni olabilecek, mukaveleden ayrı, ondan başka, bir ikinci kuvvete ihtiyac, vardır. Bu kuvvet ya maddî ya mânevî olur. Maddî oldựu takdirde, yani devletin sinesinde vatandaşlan zorla onların arzu ve iradelerine răgmen tuttuğu kabul edilecek olursa, içtimaî mukavele nazariyesinin temel direklerinden biri olan şahsî hürriyet ortadan kalkar ve onun yerini istibdat almıs bulunur ki, bu takdirde, mukavele nazariyesini ayakta tutmak imkânsızdır. Bu kuvvetin mânevî oldư̆u kabul edilirse, yani ya insanların içtimaîlik içgüdüleri veya yüksek ahlâkî veya dinî bir prensip ileri sürülürse, devletin menşeini sırf iradî bir fiil olan içtimaî mukavelede bulan nazariyeden uzaklaşılmış ve siyasî cemiyetlerin dơ̆uşu tabî̂ veya ahlâkî veyahut da dinî prensiplere băglanmış olur [41]. Görülüyor ki, içtimaî mukavele nazariyesinin ayakta durabilmesi, bu mukaveleye müstenit bir devletin stikrarının sał̆lanabilmesi için, vatandaşların muvafakatlerinin bir daha geri alınamıyacağını ispat etmek șarttır. Bu ciheti, mukavele nazariyesinin yardımı ile ispat etmek ise mümkün değildir. Esasen, mevzu bahis mukavele bir faraziye olarak telâkki edilse dahi, insan için cemiyet hayatının bir mecburiyeti olmaysp iradî bir fiil olduğunu ileri sürmek şeniyetle taban tabana zit bir iddia teşkil eder.

Bundan başka, Roussseau'ya göre aBilâ istisna herkes bütün hak ve hürriyetlerini topluluğa vermekle, her şahıs diğer șahıslar üzerinde onların kendi üzerinde sahip oldukları iktidara muadil bir iktidara malik bulunmakta, yani verdiği nispette geri almakta, kendi kendine itaat etmekte ve eskisi kadar hür ve serbest kalmaktadır.

Bu mütalâa tamamen yanlıştır. Çünkü, bir cemiyetin âzalarının birbirleri üzerinde müsavi bir iktidara sahip bulunmaları ancak iki halde mümkün olabilir. Ya, âzalardan her biri şahsî iradesiyle diğer bütün âzaları herhangi bir tasarruftan menedebilecek kudreti haiz olmalıdır ki bu takdirde herkes, diơerlerinin emirlerini tamamen aksi emirler vererek durdurabilecektir. Veyahut da karar verebilmek için mutlaka âzaların oybirlił̆inin tahakkuk

[41] Jellinek, op. cit., Cilt l, s. 342 . 
etmesi şartı bulunmalıdır. Bu takdirde ise, her şahıs, tek başına, karara iştirâkten istinkâf eylemek suretiyle hoşuna gitmiyen ka. nunların kabul edilmesinin önüne geçebilecektir.

Işte, yukarıdaki iki halde bütün vatandaşların birbirleri üzerinde müsavî bir iktidara sahip bulunduklarını ve bilhassa herkesin sadece kendi kendine itaăt ettiğini ileri sürmek doğru olabilir.

Ancak, her iki halde de, içtimaî mukavelenin bütün mânasımı kaybedeceği ve mukaveleden önceki anarşiyi önliyebileceği, siyasî bir cemiyetin muhtaç olduğu düzeni kuramyacă̆ı muhakkaktır.

Esasen Rousseau da bu iki hal çaresini teklif etmiyor ve buna mukabil azaların iętimaî mukavele ile çoğunluğun fikrine uymak prensibini kabul ettiklerini ileri sürüyor. Böyle olunca, herkesin birbiri üzerinde ayni iktidare sahip bulunduğunu iddia etmek doğru değildir. Bu taktirde her şahıs bütün iktidarından ferağat eylemiş olmasına mukabil diłger şahıs üzerinde pek cüz'î bir hak elde etmiş olur. Daha doğrusu, her şahsın diğerleri üzerindeki iktidarı onların kendi üzerinde mevcut bulunan iktidarlarmndan eğer bu şahıs azınlığa dahilse daha az, çoğunluk içinde bulunuyorsa daha fazladır, fakat hiçbir zaman buna müsavi olmaz; yani, çơ̆unluğun iradesinin hâkim olması prensibi kabul edilirse, içtimai mukavele iie insanjar ferağat ettikleri iktidarın tam mukabilini almazlar. Onların diğerleri üzerindeki iktidarn çoğunlự̆a dahil bulunup bulunmamalarına göre değişir [42]. Bundan başka, çoğunluğun iradesine tâbi olmakla insanın kendi kendine itaal ettiợini ispat etmek de güçtür. Zira eğer, içtimaî mukavelede çoğunluğun fikrine tâbi bulunmağı herkes kabul etmiştir; bu itibarla çoğunluga mutavaat netice itibariyle insanın kendi kendisine itaatı demektir; yolunda bir iddia serdolunursa, aynı mantıkla, müstebit bir kırala tàbi olmağı kabul etmiş :kimselerin veya ihtiyariyle köle olmuş bir şahsın da kırala veya efendiye itaat etmelerinin binnetice kendi kendilerine itaat ediyorlarmıs gibi telâkki eylemek pek mümkündür [43]. Nihayet herkesin bütün hak ve hürriyetlerinden topluluk lehine vazgeçmeleriyle husule gelen umumî irade, pratikte,

[4ż] B. de Villeneuve, op. cit., C. I, S. 56, De Vareilles - Sommières den naklen.

[43] Paul.L. Léon, La notion de souverainetè dans la doetrine de Roussean, Archives de Philosophie du droit et de sociologie juridique. 1938. $1 \cdot 2$, s. 25 . 
çoğunluk tarafından temsil edileceğine göre, netice itibariyle her şahıs, mutlak bir surette, bu çoğunluð̆un, yani mesuliyetsiz bir kalabalıł̆ın esiri vaziyetine düşecektir. Çogunluğun istibdadı ise istibdatların en müthişi ve en tahammülfersasıdır. -lşte bu bakımdan da insanların hürriyetlerini aslâ ihlâl etmek istemiyen mukavele nazariyesinin gayesiyle pratikte vardığı netice birbirleriyle tezat halindedirler [44].

[44] A. F. Bașgil, Esas Teşkilât hukuku derșleri, İstanbul, 1945, Cilt I Fas. I, s. 155 - 157. 